Uluslararası İktisadi ve Idari Incelemeler Dergisi
International Journal of Economic and Administrative Studies
https://dergipark.org.tr/tr/pub/ulikidince

\title{
THE NEXUS BETWEEN PUBLIC FIXED CAPITAL INVESTMENTS AND PERFORMANCE OF STATE OWNED ENTERPRISES
}

\author{
Duygu ARSLANTÜRK ÇÖLLÜ ${ }^{1}$, Emine KAYA ${ }^{2}$
}

\begin{abstract}
The aim of this study is to analyze the effects of public fixed capital investments on the performance of state-owned enterprises (SOEs). Within the scope of the study, we include the data of 20 non-financial SOEs operating in Turkey regarding the period of 2011-2018. We take into consideration the following performance dimensions: profitability and operational efficiency. Our dynamic panel data analysis results obtained after controlling the firm characteristics show that public fixed capital investments have no effect on ROA, however, have a low and positive effect on ROE and ROR. Also it was confirmed that fixed capital investments have a negative effect on ATO, LTO, and LTA, which are considered to represent operational efficiency. In brief, the results indicate that the public fixed capital investments have a partial and positive effect on the profitability, while it is a negative effect on the operational efficiency.
\end{abstract}

Keywords: SOE, Public Fixed Capital Investments, Firm Performance.

JEL Classification: G31, H32, H54.

\section{KAMU SABIT SERMAYE YATIRIMLARI VE KAMU IKTISADi TEŞEBBÜSLERININ PERFORMANSI ARASINDAKI ILIŞKi}

Öz

Bu çalışmanın amacı, kamu sabit sermaye yatırımlarının Kamu İktisadi Teşebbüsleri (KiT)'nin performansı üzerindeki etkilerini incelemektir. Çalışma kapsamında, Türkiye'de faaliyet gösteren, finansal olmayan 20 adet KiT'in 2011-2018 dönemine ait verileri kullanıımıştır. Firma performansının göstergesi olarak mevcut çalışmada karlıık ve operasyonel verimlilik dikkate alınmıştır. Firma özelliklerini kontrol ettikten sonra elde edilen dinamik panel veri analizi sonuçları, kamu sabit sermaye yatırımlarının karlılık göstergelerinden ROA üzerinde herhangi bir etkisinin olmadığını, ancak ROE ve ROR üzerinde düşük ve pozitif yönlü bir etkiye sahip olduğunu göstermektedir. Diğer taraftan sabit sermaye yatırımlarının operasyonel verimliliği temsil ettiği düşünülen ATO, LTO ve LTA üzerinde ise olumsuz bir etkisinin olduğu teyit edilmiştir. Özetle mevcut çalışma sonuçları, kamu sabit sermaye yatırımlarının karlılı̆ı kısmi ve olumlu yönde, operasyonel verimliliği ise olumsuz şekilde etkilediğini göstermektedir.

Anahtar Kelimeler: KiT, Kamu Sabit Sermaye Yatırımları, Firma Performansı.

JEL SInıflandırması: G31, H32, H54.

${ }^{1}$ Dr. Öğr. Üyesi, IğdırÜniversitesi iliBF, işletme Bölümü, duygu.arslanturk@igdir.edu.tr, ORCID: 0000-0002-8023-3888. ${ }^{2}$ Doç. Dr. Malatya Turgut Özal Üniversitesi Sosyal ve Beşeri Bilimler Fakültesi, Muhasebe ve Finans Bölümü, emine.kaya001 @hotmail.com, ORCID: 0000-0002-7035-9241. 


\section{Introduction}

The spread of neo-liberal policies across the world made the privatization and market competition dominant trends among the economic reforms. This situation brought up for discussion the question to what extent the SOEs would be able to serve as an intermediary for national industrial development in the global market integration period (Sing and Chen, 2017). In the same period, the reformers who highlighted the role and size of government in market economies began to question the size and tasks of SOEs in state-market debate (Naveed et al., 2018). In this context, SOEs were accused of low performance due to ownership structure in relevant studies (Boardman and Vining, 1989; Megginson et al., 1994; Bavon, 1998; Dewenter and Malatesta, 2001; Megginson and Netter, 2001) and the privatization was promoted in a sense. Therefore, the policies which are liberalization and privatization that have actively emerged for the last three decades caused a considerable decrease in the number of SOEs in many countries. However, although private ownership is the dominant ownership type in market-based societies, it is also possible to come across the state ownership (Goldeng et al., 2008).

In the traditional public finance approach, state intervention is often seen as an effective method for solving market failures such as inadequate provision of public goods or the presence of externalities in the consumption or production of a private good. According to this view, the objectives of the politicians that affect public enterprises are consistent with those of public and state enterprises. Hence, politicians help to maximize social welfare while they are trying to achieve an efficient result by internalizing social costs in the production decision process. (Billon and Gillanders, 2014). Within this scope, SOEs constitute a considerable part of most economies including the developed economies that operate in some strategic sectors such as energy, minerals, infrastructure, other public services, and financial services in some countries (OECD, 2018). Especially in developing countries where unemployment and inequality are more easily associated with political instability, they have a particular importance since SOEs make contributions to the field of some social policies and objectives. Considering the underdeveloped nature of resources and sectors in such markets, the production to be realized by SOEs is essential for development (Hemming and Mansoor, 1987).

Due to various reasons such as ensuring economic development, operating monopolies by the state, performing the businesses that the private sector could not achieve or attempt, directing the economy, leading the private sector, and regulating the distribution of income, the intervention of and attempt by the state in economic life in Turkey became a necessity and in modern terms SOEs began to be established in the 1930s (Public Enterprise Report, 2019: 4). The importance and dominance of the SOEs that were established with social and economic purposes in the economy continued until the 2000s. The privatization program started in 1984 to accelerate the structural transformation and modernize the economy (OECD, 2016: 84) and privatizations have accelerated by the 2000s within the frame of economic stability programs and International Monetary Fund (IMF) supported programs for the state to withdraw from economic activities. Thus the number of SOEs, which was 49 in 2001, thereby reduced to 25 in 2010 . The number of SEOs in Turkey is 28 by the end of 2018 . This situation has paved the way for a gradual decrease in the contribution of SOEs to the economy. Graph 1 indicates the contribution of the SOEs to GDP by years.

Despite all attempts to privatization, the SOEs in Turkey still operate in strategic and capital intensive sectors such as energy, mining, and transportation. Although the decrease in their number indicates that their economic contribution has decreased, the SOEs continue to make a significant amount of fixed capital investments in the aforementioned sectors. As seen in Graph 2 , the share of fixed capital investments in the GDP created by SOEs (SOEFCI/SOEGDP) is higher than the share of the country's fixed capital investments in the country GDP (TRFCl/TRGDP) except for the period of 1995-2010 where privatization was maximum. 
Graph 1: Contribution of SOEs to GDP

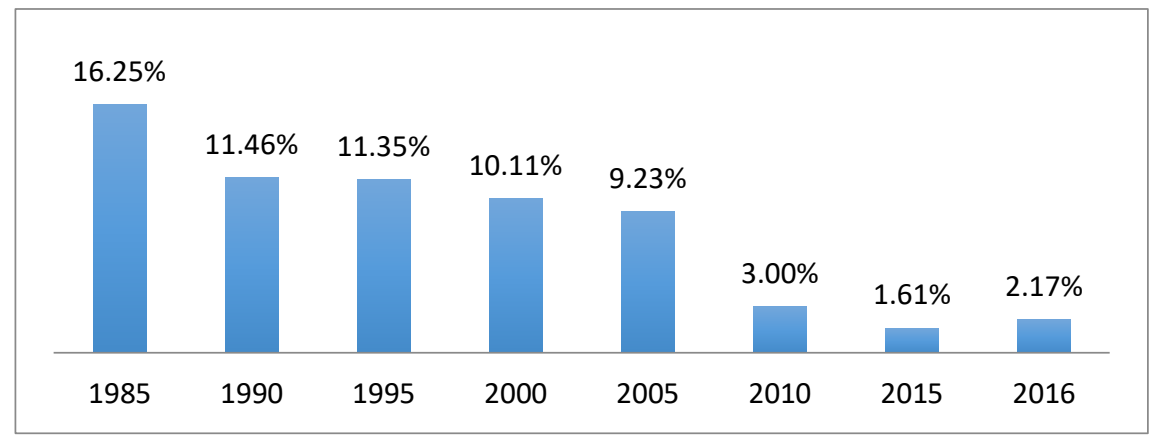

Source: Supreme Audit Institution Report (2012), Public Enterprises Report (2017)

Graph 2: Contribution of Fixed Capital Investments to GDP

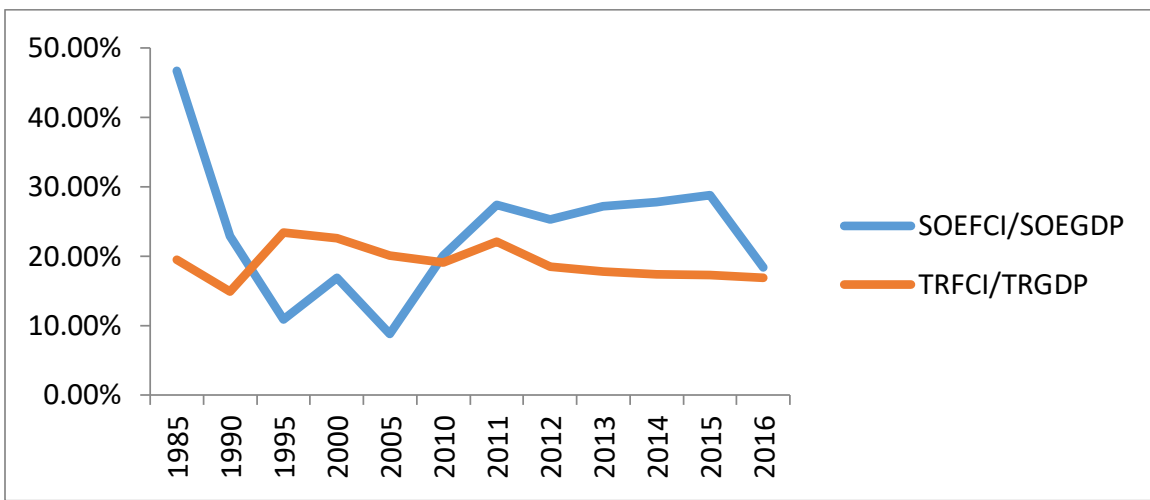

Source: Supreme Audit Institution Report (2012), Public Enterprises Report (2017)

One of the most important theoretical bases of public entrepreneurship is that the private sector does not have the capital accumulation to establish enterprises that require large scale investments. In this context, the SOEs play a critical role for Turkish economy, thanks to their public fixed capital investments in terms of added value which they created, their contribution to capital accumulation, and being a leader in some sector and technology investments industrialization (Incekara, 1989). Maria-Dolores (2004) states that there is a standard assumption in the literature that public infrastructure shifts an average production function upward. Besides, there is a need for a considerable amount of public fixed capital investment to develop required social and physical infrastructure, protect the environment, comply with Europen Union (EU) criteria, and reduce the development disparities compared to developed countries and between the regions for increasing the competitiveness and maintaining sustainable development (Public Enterprise Report, 2017). This indicates that fixed capital investments will continue both by the SOEs and other public institutions.

De Long and Summers (1991) revealed that the increase in the share allocated to fixed capital investments in GDP is associated with GDP increase. As a matter of fact, the classical macroeconomic theory argues that economic growth depends on fixed capital investments or gross fixed capital formation. In this sense, the studies on economic growth generally focus on capital formation (Tvaronavičius and Tvaronavičiene, 2008) and empirical studies (Lipsey and Kravis, 1987; De Long and Summers, 1991; Levine and Renelt, 1992; Mankiw et al., 1992; Abiad et al., 2015) show that fixed capital investments have a significant impact on the economic growth.

It is known that the effects of fixed capital investments, which are generally examined at the macroeconomic level, have considerable reflections at the microeconomic level as well. Lev and Thiagarajan (1993) points out that capital investment growth could be considered as a positive signal about firms' future earnings and cash flows. In the literature, there is a positive correlation

\section{Uluslararası İktisadi ve İdari İncelemeler Dergisi}


between firm size, firm growth, and firm efficiency and the increase in the investments of firms which make capital investments by the need for new machinery and equipment to meet an increasing demand, keep in step with technological innovations or produce a new product (Grazzi et al., 2016). Within this scope, Grozdic et al. (2020) expects a positive relationship between fixed capital investments and firm performance. Also, Grozdic et al. (2020) split the capital investments at the firm level into two groups in terms of short-term and long-term results. Accordingly, even if the fixed capital investments seem to be a loss for the firm in the short term, it increases firm performance in the long term.

Investment activities are supported by two sectors, public and private. The present studies generally focus on the private investments (Fama and French, 1999; Johansson and Lööf, 2008; Aktas et al., 2015; Grazzi et al., 2016). On the other hand, the studies on the effect of public fixed capital investments, which are supported by the state at firm-level, research the investment efficiency rather than the effect of the aforementioned investments on performance (Dollar and Wei, 2007; Chen et al., 2011; Ljungqvist et al., 2015; Opie et al., 2019; Huang, 2019). This situation makes it important to measure the impact of public fixed capital investments on the performance of SOEs. Therefore, the motivation of the present study is to explore the effects of public fixed capital investments on SOEs' performance.

We expect this study to provide some contributions to the literature. This is the first study that comprehensively examines the relationship between the public fixed capital investments and SOEs' performance for Turkey. Another contribution of the study to the literature is related to performance measurement. Indeed, we conduct the measure of SOEs performance with two aspects: profitability and operating efficiency and thus, we analyze SOEs performance in many dimensions. Multidimensional performance measurement is an important key factor in terms of detailing the findings and obtaining deep information about the firm performance for SOEs. The other contribution of the study to the literature is the robustness checks and we provide evidence with robustness checks estimations about the stable effect of public fixed capital investments on SOEs' performances. On the one hand, this study contributes to the literature to detect the determining factors about SOEs' performance; on the other hand, it can provide information that may help policymakers and SOEs' managers on public fixed capital investment decisions in the future.

The present study that investigates the effect of public fixed capital investments on the SOEs' performance consists of four sections. Following the introduction, the relevant literature is presented in the first section. The data set is introduced in the second section while methodology and hypotheses are discussed in the third section. Section four is related to the findings of the analysis and finally, in the conclusion, the results are generally evaluated.

\section{Literature}

Theoretically, fixed capital investments are expected to have a positive effect on economic growth. In this context, it is believed that the SOEs investing substantial amounts of public fixed capital will support economic growth, especially in underdeveloped and developing countries. However, some studies argue that SOEs, which are non-productive at the micro-level, decrease economic growth or absorbing scarce resources that can be used by private enterprises more efficiently (Qi and Kotz, 2019). Pratuckchai and Patanapongse (2012) argue that the SOEs, which constitute a significant part of the global economy, tend to be less efficient than similar private enterprises and are associated with lower economic growth in the developing countries due to the lack of incentives related to state ownership. Khan and Reinhart (1990) find that private investments have a greater impact on economic growth than public investments by making a distinction between private and public components of investment for a developing country example. On the other hand, Keefer and Knack (2007) suggest that countries where public institutions are weak, public investments are considerably higher. 
There is a limited number of studies which investigate the microeconomic effects of fixed capital investments in the literature and it is generally focused on the relationship between economic growth and fixed capital investments (Grazzi et al., 2016). The results of the aforementioned researches are controversial. Accordingly, Jindrichovska et al. (2013), Aktas et al. (2015), Alipour et al. (2015) argue that fixed capital investments have a negative effect on profitability, whereas Fama and French (1999), Johansson and Lööf (2008), Aw et al. (2008), Sudiyatno et al. (2012), Grazzi et al. (2016), Yu et al. (2017) and Grozdic et al. (2020) suggest that the fixed capital investments have a positive effect on profitability. In addition, the studies in the relevant literature mostly researched private firms and private investments. On the other hand, we can see that there is a limited number of studies that investigate the effect of public fixed capital investments by SOEs on the profitability or efficiency of firms. Within this scope, O'toole et al. (2015) investigate the relationship between Tobin $Q$ ratio and investments in terms of ownership. The study conducted in Vietnam, investment expenditures were found not to have a relation with SOEs' marginal returns in all sectors and size classes. It was stated that this picture is caused by investment activities of SOEs, unlike private firms, which are not directed only with the concern of profitability and the focus was on social policy and political objectives ( $O$ 'toole et al., 2015). In addition, Assagaf and Ali (2017), analyze the financial performances of seven SOEs operating in Indonesia and use the SOEs fixed capital investments as a control variable while investigating the effect of subsidies on performance. However, fixed capital investments are found not to have a significant effect on SOEs' financial performance.

On the other hand, Fernández-Rodríguez et al. (2019) find that the tax burden of SOEs in Spain is affected by leverage and fixed asset growth which is described as capital intensity. It is stated that the SOEs encounter a lower effective tax rate (tax expense/pretax expense) when their capital intensity increases. This finding argues that either tax revenue declines or pretax income increases while SOEs' fixed asset growth increases.

Robinson and Torvik (2005) claim that underdevelopment is related with the lack of investment; however, the investment growth does not necessarily result in output growth, although the investment volume is high in developing countries. This indicates that not only the lack of investment is important but also inappropriate distribution of investments (Robinson and Torvik, 2005:197). Hence, it should be noted that the investment efficiency is as important as the amount of investment. The studies on SOEs generally put an emphasis on the inefficiency of investment. As a matter of fact, Boycko et al. (1993) suggested that states would be willing to invest to a large extent in an inefficient way to increase employment and achieve other social purposes. Similarly, it is suggested in the ninth chapter of their book named "The Grabbing Hand" by Shleifer and Vishny (1998) that politicians tend to convince managers to overinvest in an attempt to obtain political benefit; however, the managers do not like this situation on the grounds that it damages the interests of their stakeholders.

Inefficiency of fixed capital investments is underlined through some studies on Chinese SOEs. Chen et al. (2011) argue that the sensitivity of investment expenses to investment opportunities is low for SOEs, while Ljungqvist et al. (2015) argued that SOEs failed in investment spending and capital allocation. Also, an et al. (2016) provide evidence that SOEs have lower investment efficiency compared to private firms, while Chen et al. (2017) provided evidence of inefficient capital allocation in Chinese state-owned enterprises by showing greater capital flows to units with fewer investment opportunities in these companies. Similarly, Bahadur (2004) reveals that SOEs are not able to provide satisfactory financial returns over the capital allocated despite sizeable capital investments in Nepal. Dollar and Wei (2007), as well, give evidence that the capital in SOEs is allocated inefficaciously. Furthermore, Dollar and Wei (2007) state that SOEs provide significantly lower marginal returns to capital compared to domestic private or foreignowned firms. All these studies show that there are some factors that distort the optimal investment behavior of SOEs. Stein (2003) put forward that information asymmetry and agency conflict are the most common and important factors that cause deviation from optimal

Uluslararast İktisadi ve İdari İncelemeler Dergisi 
investment behavior. Also, Chen et al. (2011) state that intervention in SOEs through the appointment of managers with a political background distorted the investment behavior and harms investment efficiency.

\section{Data}

We comprehensively investigate the effect of public fixed investment on SOEs' performances for Turkey in this study. To explore the definition of SOEs is an important situation. SOE is defined as a firm in which the State Treasury has a share of a minimum 50\% (Köseoğlu, 2005; The Tenth Development Plan, 2014; Kabaciński et al., 2020). Therefore, SOEs have state ownership and state control in the management (Christiansen, 2011; Bałtowski and Kozarzewski, 2016; Szarzec and Nowara, 2017). Kabaciński et al. (2020) argue that SOE is a very large-scaled firm if the number of employees is greater than 1,000 people. In Turkey, only two SOEs do not have employees greater than 1,000 people, therefore SOEs in Turkey are very large-scaled firms.

In recent years, SOEs emerge as an important economic agent, being considered as instruments of economic development in the sectors (Bernier, 2014). On the other hand, the public fixed capital investments are important for growth and economic development (Grozdi'c et al., 2020). SOEs were established in Turkey in general for economic reasons. The acceleration of industrialization had been through public investments in Turkey, and SOEs had played an important role in the development of Turkey economy. This situation makes it important to measure the impact of public fixed capital investments for Turkey. Thus, we research the public fixed capital investment effects on SOEs and within this scope, we focus on the performances of SOEs. For this purpose, we use the public fixed capital investments as an independent variable. The public fixed capital investment variable is fixed capital investments supported by the government and we include in the analysis as it annual change.

We examine SOE performances for two aspects following Aivazian et al. (2005) and Chan et al. (2018). Two aspects of SOEs performance are profitability and operating efficiency. Boardman and Vining (1989) assert that the profitability and operating efficiency can be investigated separately. Boardman and Vining (1989) argue that profitability and operating efficiency are two distinct terms, but they are equally important dimensions of firm performance. The profitability aspect of firm performances consists of return on equity (ROE), return on asset (ROA), and return on revenue (ROR). We measure ROE, ROA, and ROR as the ratio of profits after tax and interest to the equity, the ratio of profits after tax and interest to the total assets, and the ratio of profits before tax and interest to the net revenue for the firm $i$ in $t$ year, respectively.

The operating efficiency aspect includes the asset turnover (ATO), labour turnover (LTO), and labour intensity (LTA). We calculate ATO, LTO, and LTA as the ratio of net revenue to the total assets, the ratio of net revenue to the total employment, and the ratio of total employment to the total assets for every firm in t year, respectively. ATO consists of LTO and LTA. In line with Chan et al. (2018), we take into account all together ATO, LTO, and LTA measurements and therefore we find an opportunity to explore different aspects of operating efficiency. One the hand, these performance measurements are generally used in the existing literature for comparing relative performances of SOEs, on the other hand, these ratios are employed for the private firm performance analysis (Megginson et al., 1994; Dewenter and Malatesta, 2001; Bradbury and Hooks, 2008; Chan et al., 2018).

To capture firm-level characteristics, we include the control variables to the models. The first one is Conc as discussed by Chan et al. (2018), Çevik (2020), Kabaciński et al. (2020). Conc is the concentration in the industry. We measure Conc as the share of employment or revenue of the firm in the total industry in a financial year following Çevik (2020) and Chan et al. (2018). We use also other control variables such as age, size, and leverage as suggested by Dewenter and Malatesta (2001), Aivazaian et al. (2005), Bradbury and Hooks (2008), Ejelly (2009), Chan et al. (2018), Opie et al. (2019), Çevik (2020), and Kabaciński et al. (2020). Age is the log number of 
years since establisment for a firm, size is the log of total assets, and finally, leverage is the ratio of long-term and short-term debts to the total assets, for the firms in $t$ year.

For the data cleaning principles, as suggested by Gal (2013) and Kalemli-Özcan et al. (2015), we do not include the observations where total assets, tangible fixed assets, employment, operating revenue, and sales in any financial year are missing. Moreover, we include only firms with at least two consecutive years of reporting in the observation. We follow the literature (Çevik, 2020; Kabaciński et al., 2020) and we winsorize 1 and 5 percent of observations to minimize the effect of possibly spurious outliers. The firm-level dataset of SOEs covers the annual observations as the 2001-2018 time period for Turkey. We include 20 firms operating as SOE, which we can obtain the balance sheets and income statements data. As a matter of fact, there are 20 non-financial SOEs in 2020 for Turkey. Thus, we include all SOEs in the scope of the study. In line with Kabaciński et al. (2020), we avoid double counting and we focus on the consolidate financial data for SOEs.

Our financial dataset consists of the non-financial firms. We do not include the financial firms although there are eight financial SOEs in Turkey. Because the financial firms have high leverage and this situation can affect the findings (Kabaciński et al., 2020). On the other hand, Fama and French (1999) and Grozdi'c et al. (2020) do not include in the dataset the financial firms in their study. We try to remove biased findings, therefore we standardize the variables by following Arnull and Almond (2008) and Kabaciński et al. (2020).

When we look at the sectoral distribution of 20 SOEs for Turkey, we determine that four firms operate in the transportation sector, six firms operate in the energy sector, three firms operate in the agricultural sector, two firms operate in the mining sector, four firms operate in the manufacturing sector, and finally one firm operates in the retail sector. We obtain the public fixed capital investment variable from The Republic of Turkey of Strategy and Budget Presidency. We receive the public sector revenues data from the Republic of Turkey of the Ministry of Treasury and Finance. We obtain the firm-level data including balance sheets and income statements of the SOEs from their annual financial reports. At the end of each year, SOEs announce their annual balance sheets and income statements on their official website. In Table 1 , we summary the descriptive statistics of variables included the this study.

In Panel A of Table 1, we can see that the most volatile variable is LTA with 0.61 standard deviation but Leverage has the highest mean with 0.43 . Size (Asset) follows Leverage for the highest mean value. ROE and ROR have close standard deviations to each other. On the other hand, there are differences in mean values for ROE, ROA, and ROR. When we compare LTA, LTO, and ATO standard deviation and mean values, we determine that one the hand, their mean values are close to each other on the other hand, their standard deviations are different from each other. Moreover, the investment variable does not have a low mean and this situation is associated with a growth rate of public fixed capital investment.

In Panel A of Table 1, ROE and ROA have negative means and this situation shows that SOEs operate heavy losses. The high mean value of Leverage with 0.43 indicates that SOEs finance about half of the assets by the dept. With a 0.35 mean value, Size (Asset) has one of the high mean values in Panel A of Table 1. The mean value of Conc (Employment) is 0.23 . Generally, SOEs operate under oligopoly market conditions and Kim et al. (2019) assert that if the concentration rate in an industry is higher than 0.1 , this rate indicates that the industry is an oligopoly market. Thus, 0.23 mean value of Conc (Employment) is evidence of an oligopoly market in Turkey.

Panel B of Table 1, which includes variables for robustness checks estimations, shows that the most volatile variable is LTA with 1.71 standard deviation like Panel A. LTA has 0.14 a mean value, indicating SOEs do not have low efficiency, but the means of ATO and LTO are not high. Conc (Revenue) has a high mean value with 0.38 and this finding provides evidence that SOEs operate in a low-competition industry where a small number of large firms dominate.

\section{Uluslararası Íktisadi ve İdari İncelemeler Dergisi}


Table 1: Descriptive Statistics of Variables for SOEs

\begin{tabular}{lcccc}
\hline \multicolumn{5}{c}{ Panel A. (Winsorize procedure is based on 1 percent) } \\
Variables & Mean & Standard Deviation & Maximum & Minimum \\
ATO & 0.03 & 0.03 & 0.83 & 0.03 \\
LTO & 0.02 & 0.23 & 0.19 & 0.09 \\
LTA & 0.01 & 0.61 & 0.09 & 0.01 \\
ROE & -0.03 & 0.13 & 0.08 & -0.05 \\
ROA & -0.12 & 0.39 & 3.61 & -0.11 \\
ROR & 0.01 & 0.18 & 0.14 & 0.08 \\
Age & 0.13 & 0.15 & 2 & 0.67 \\
Investment & 0.29 & 0.17 & 1.54 & 0.01 \\
Size (Asset) & 0.35 & 0.12 & 1.88 & 0 \\
Leverage & 0.43 & 0.4 & 4.99 & -0.01 \\
Conc (Employment) & 0.23 & 0.15 & 1.9 & 0.11 \\
\hline & Panel B. (Winsorize procedure is based on 5 percent) & \\
Variables & Mean & Standard Deviation & Maximum & Minimum \\
ATO & 0.04 & 0.13 & 2.07 & 0.02 \\
LTO & 0.09 & 0.38 & 3.45 & 0.43 \\
LTA & 0.14 & 1.71 & 0.55 & -0.11 \\
ROE & -0.02 & 0.08 & 0.15 & -0.73 \\
ROA & -0.06 & 0.27 & 0.18 & -0.23 \\
ROR & 0.05 & 0.84 & 7.95 & -0.7 \\
Investment & 0.44 & 0.34 & 1.42 & 0.02 \\
Age & 0.54 & 0.36 & 2.13 & 0.73 \\
Size (Sales) & 0.51 & 0.54 & 1.49 & 0.1 \\
Leverage & 0.48 & 1.64 & 5.63 & 0.3 \\
Conc (Revenue) & 0.38 & 0.4 & 1.42 & 0.09 \\
\hline
\end{tabular}

Leverage has a 0.48 mean value in Panel B and we can see that about half of the assets are financed by the dept for SOEs. The main variable Investment does not low, and its growth rate is high. But a high investment growth rate does not show high investment productivity and efficiency for SOEs (Aivazian et al., 2005). Panel B presents there are negative means for ROA and ROE in line with the findings in Panel A. In brief, findings Panel A and Panel B are approximately similar. Table 2 gives the pairwise correlations for the variables.

In Panel A and Panel B of Table 2, Investment is in the positive relationship between profitability and operating efficiency measurements except for LTA and LTA. In addition, the correlations between profitability and operating efficiency measurements are statistically significant most of the findings. Size (Asset) and Size (Sales) have approximately similar effects on the profitability and operational efficiency measurement. In Panel A and Panel B of Table 2, there are statistically significant differences in the correlations between Conc (Revenue) and Conc (Employment) and the other variables, but these differences are not high. 


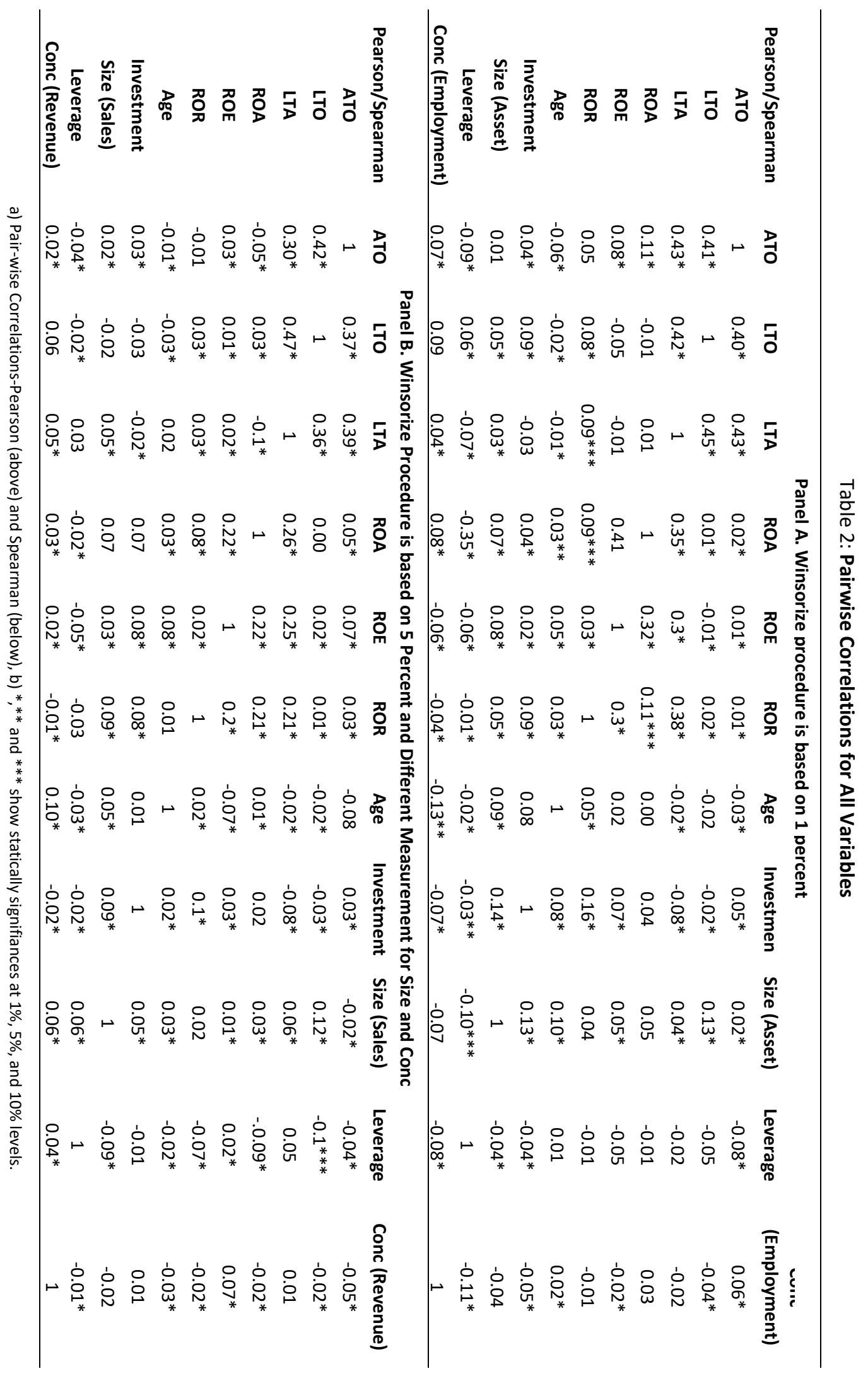




\section{Econometric Methodology and Hypothesis Development}

To determine the relationship between SOEs' performances and public fixed capital investments, we estimate dynamic panel data analysis. We employ the System Generalized Method of Moments (GMM) technique proposed by Arellano and Bover (1995) and Blundell and Bond (1998) for dynamic models in this study. GMM helps to correct the estimation biases caused by the inclusion of the lagged dependent variable, as well as the joint endogeneity of independent variables. Thus, we use the System GMM in this study.

GMM estimator employes the internal instruments by bringing together in the levels with variables in first differences, assuming that the error terms are not serially correlated and the independent variables are weakly exogenous or not significantly correlated with future realizations of the error terms (Çevik, 2020). We estimate the following dynamic panel models to determine the relationship between SOEs performances and fixed capital investments:

$$
\begin{aligned}
& R O E_{i t}=\delta_{0} R O E_{i t-1}+\delta_{1} \text { Investment }_{i t-1}+\delta_{2} \text { Age }_{i t-1}+\delta_{3} \text { Leverage }_{i t-1}+\delta_{4} \text { Size }_{i t-1}+ \\
& \delta_{5} \text { Conc }_{i t-1}+\eta_{i}+\gamma_{t}+\varepsilon_{i t} \\
& R O A_{i t}=\delta_{0} R O A_{i t-1}+\delta_{1} \text { Investment }_{i t-1}+\delta_{2} \text { Age }_{i t-1}+\delta_{3} \text { Leverage }_{i t-1}+\delta_{4} \text { Size }_{i t-1}+ \\
& \delta_{5} \text { Conc }_{i t-1}+\eta_{i}+\gamma_{t}+\varepsilon_{i t} \\
& R O R_{i t}=\delta_{0} R O R_{i t-1}+\delta_{1} \text { Investment }_{i t-1}+\delta_{2} \text { Age }_{i t-1}+\delta_{3} \text { Leverage }_{i t-1}+\delta_{4} \text { Size }_{i t-1}+ \\
& \delta_{5} \text { Conc }_{i t-1}+\eta_{i}+\gamma_{t}+\varepsilon_{i t} \\
& A T O_{i t}=\delta_{0} A T O_{i t-1}+\delta_{1} \text { Investment }_{i t-1}+\delta_{2} \text { Age }_{i t-1}+\delta_{3} \text { Leverage }_{i t-1}+\delta_{4} \text { Size }_{i t-1}+ \\
& \delta_{5} \text { Conc }_{i t-1}+\eta_{i}+\gamma_{t}+\varepsilon_{i t} \\
& L T O_{i t}=\delta_{0} L T O_{i t-1}+\delta_{1} \text { Investment }_{i t-1}+\delta_{2} \text { Age }_{i t-1}+\delta_{3} \text { Leverage }_{i t-1}+\delta_{4} \text { Size }_{i t-1}+ \\
& \delta_{5} \text { Conc }_{i t-1}+\eta_{i}+\gamma_{t}+\varepsilon_{i t} \\
& L T A_{i t}=\delta_{0} L T A_{i t-1}+\delta_{1} \text { Investment }_{i t-1}+\delta_{2} \text { Age }_{i t-1}+\delta_{3} \text { Leverage }_{i t-1}+\delta_{4} \text { Size }_{i t-1}+ \\
& \delta_{5} \text { Conc }_{i t-1}+\eta_{i}+\gamma_{t}+\varepsilon_{i t}
\end{aligned}
$$

In the equations above, lagged dependent variables contain dynamic adjustments in firms' performances to changes in the other variables, $\varepsilon_{i t}$ is the idiosyncratic error term. $\eta_{i}$ and $\gamma_{t}$ are time-specific and individual effects, respectively.

We employ a number of robustness checks to examine the stability of obtained results and findings. We conduct robustness checks as the following process:

- We focus the sales as a second measurement for size.

- We estimate static panel data analysis as a different econometric method for estimation.

- We choose the revenue as a second measurement for the revenue share in the industry.

- We winsorize 5 percent as an alternative winsorize procedure for observations.

We estimate the static version of panel models as below:

$$
\begin{aligned}
& \text { ROE }_{i t}=\delta_{0}+\delta_{1} \text { Investment }_{i t-1}+\delta_{2} \text { Age }_{i t-1}+\delta_{3} \text { Leverage }_{i t-1}+\delta_{4} \text { Size }_{i t-1}+ \\
& \delta_{5} \text { Conc }_{i t-1}+\eta_{i}+\gamma_{t}+\varepsilon_{i t} \\
& \text { ROA }_{i t}=\delta_{0}+\delta_{1} \text { Investment }_{i t-1}+\delta_{2} \text { Age }_{i t-1}+\delta_{3} \text { Leverage }_{i t-1}+\delta_{4} \text { Size }_{i t-1}+ \\
& \delta_{5} \text { Conc }_{i t-1}+\eta_{i}+\gamma_{t}+\varepsilon_{i t} \\
& \text { ROR }_{i t}=\delta_{0}+\delta_{1} \text { Investment }_{i t-1}+\delta_{2} \text { Age }_{i t-1}+\delta_{3} \text { Leverage }_{i t-1}+\delta_{4} \text { Size }_{i t-1}+ \\
& \delta_{5} \text { Conc }_{i t-1}+\eta_{i}+\gamma_{t}+\varepsilon_{i t} \\
& \text { ATO }_{i t}=\delta_{0}+\delta_{1} \text { Investment }_{i t-1}+\delta_{2} \text { Age }_{i t-1}+\delta_{3} \text { Leverage }_{i t}+\delta_{4} \text { Size }_{i t-1}+ \\
& \delta_{5} \text { Conc }_{i t-1}+\eta_{i}+\gamma_{t}+\varepsilon_{i t}
\end{aligned}
$$




$$
\begin{aligned}
& \text { LTO }_{i t}=\delta_{0}+\delta_{1} \text { Investment }_{i t-1}+\delta_{2} \text { Age }_{i t-1}+\delta_{3} \text { Leverage }_{i t-1}+\delta_{4} \text { Size }_{i t-1}+ \\
& \delta_{5} \text { Conc }_{i t-1}+\eta_{i}+\gamma_{t}+\varepsilon_{i t} \\
& \text { LTA }_{i t}=\delta_{0}+\delta_{1} \text { Investment }_{i t-1}+\delta_{2} \text { Age }_{i t-1}+\delta_{3} \text { Leverage }_{i t-1}+\delta_{4} \text { Size }_{i t-1}+ \\
& \delta_{5} \text { Conc }_{i t-1}+\eta_{i}+\gamma_{t}+\varepsilon_{i t}
\end{aligned}
$$

Public fixed capital investment for a firm can be realized in one year, or in more than one year, while benefits are usually obtained through future years after realization. In accordance with this long-term nature of fixed capital investments, fixed capital investments from the previous year should affect firm performance in the next year. Accordingly, we determine our main research hypotheses as follows:

Hypothesis 1: Public fixed capital investments have a positive effect on the profitability of SOEs.

Hypothesis 2: Public fixed capital investments have a positive effect on the operating efficiency of SOEs.

\section{Empirical Findings}

We firstly estimate the results of dynamic estimations in Table 3. The values of AR (1) and $A R(2)$ in Table 3 are the p-values first- and second-order autocorrelated disturbances. As we expect, there is not first-order and second-order autocorrelation. Similarly, the Hensen J-test findings shows that the internal instruments used in the dynamic models are valid. Wald $\chi^{\wedge} 2$ test results are evidence that each model as a whole is significant.

In GMM 1 of Table 3, we can see that the main determinants of ROE have significant signs as expected. ROE is fluctuated by its lagged values. At the $1 \%$ significance level, the previous period values of ROE are affected by the current period ROE values and this finding proves that the ROE is persistent. Moreover, a statistically significant coefficient of Investment variable shows that the public fixed capital investments are among the factors affecting profitability such as ROE. On the other hand, Age, Size, and CONC variables have a positive coefficient on GMM 1. These findings provide evidence that Age, Size, and CONC factors are key important factors for ROE such as public fixed capital investments.

On the other hand, Leverage variable has a negative coefficient in GMM 1 of Table 3, and Leverage variable negatively affects ROE variable as expected. Joh (2003) states that high leverage causes decreasing ROE. Chan et al. (2018) and Çevik (2020) argue that Leverage is in negative relation with $R O E$ in line with our results.

GMM 2 results of Table 3 are evidence that ROA variable is significantly affected by its previous values, but the Investment variable is not an important factor for ROA. Aljinovi'c and Muminovi'c (2013) examine the possible explanation for an insignificant effect of investment on the ROA and they express that this situation can be due to in the time lag between the moment of investment and future investment profitability. Moreover, Age, Leverage, Size, and CONC are significant factors for ROA in line with the findings in GMM 1 of Table 3. The age variable has a positive effect on ROA similar to the findings of GMM 1 inTable 3 . This result is emphasized by Kabaciński et al. (2020). Kabaciński et al. (2020) show that the older firms have higher performance due to accumulated knowledge and experience in the industry for SOEs.

ROR variable has persistency and is affected by its lagged values statically significant in GMM 3 of Table 3. As a main independent variable, public fixed capital investment positively change ROR as expected. In GMM 3 of Table 3, we can see that Size is an important factor for ROR variable. This finding is evidence that larger firms are more profitable than smaller firms. Also, Grozdi'c et al. (2020) argue that larger firms have a larger profitability as they produce at a lower cost per unit.

\section{Uluslararası Íktisadi ve İdari İncelemeler Dergisi}




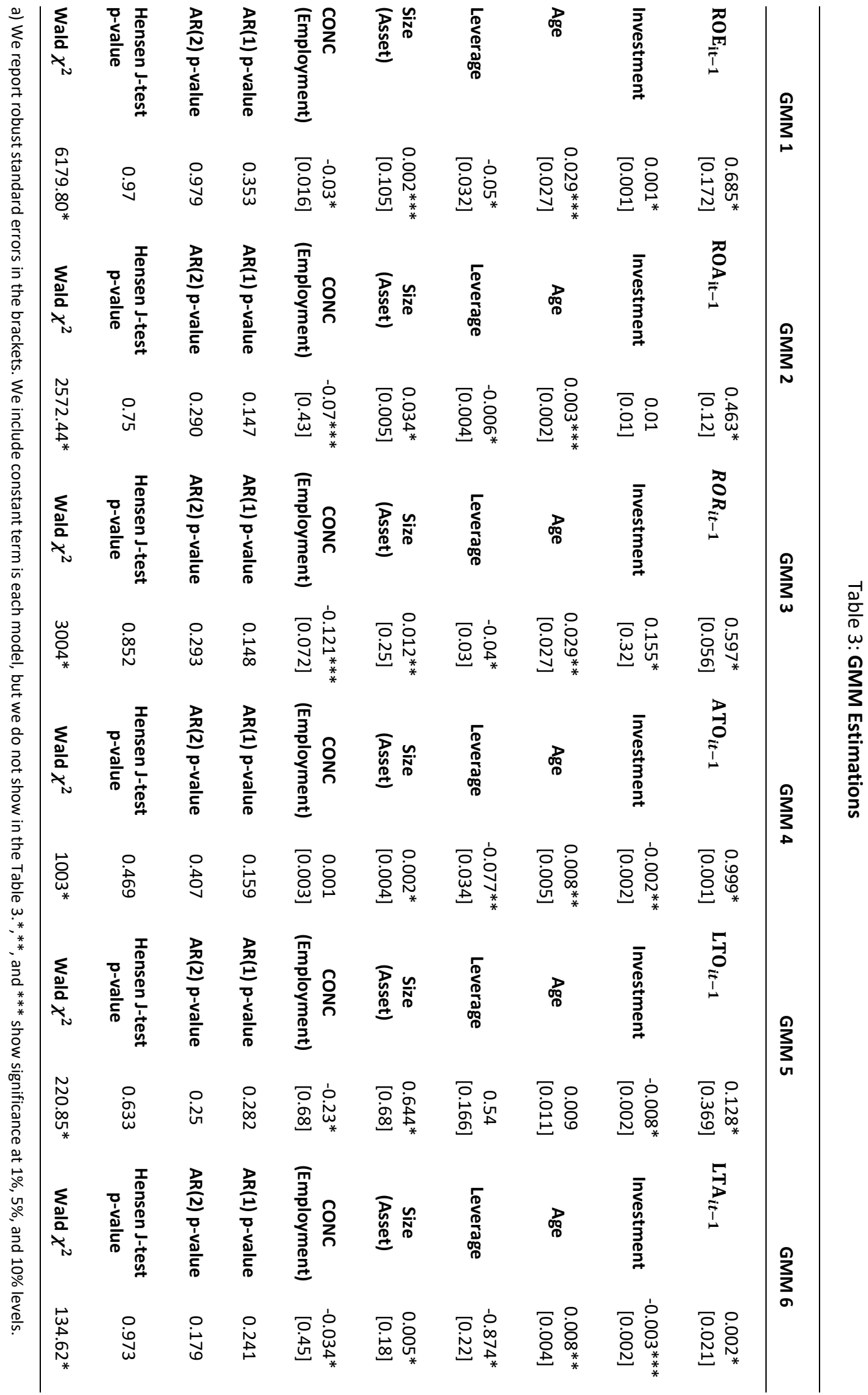


In GMM 4 of Table 3, ATO is affected by its lagged values and has persistency. When we control Size, Leverage, and Age, our main independent variable, which is Investment, has an explanatory power on ATO. The results of GMM 4 in Table 3 indicate that public fixed capital investment has a significant and negative effect on ATO. This finding is surprising and the direction of the relationship between ATO and investment is contrary to our findings, it is not as expected. Chan et al. (2018) support our findings and determine that public fixed capital investment has a negative effect on ATO. Chan et al. (2018) link this result to the mechanical relationship between ATO and assets. As well as, this finding proves that SOEs do not manage well the firm's assets. As will be remembered, GMM 2 of Table 3 shows that the Investment variable has no significant effect on the ROA variable. Moreover, CONC is not an important explanatory variable for ATO in Table 3. But it has an explanatory power for the other profitability and operating efficiency measurements in Table 3. High CONC negatively affects the SOEs performances and makes it difficult to survive (Kim et al. 2019).

In GMM 5 of Table 3, we determine that Investment is significantly important for LTO. It has a negative direction coefficient. Excess LTO is an indicator of low efficiency and therefore high investments can increase the labour turnover for SOEs. Within this scope, our result is in line with the literature (Chan, 2018). On the other hand, LTO is affected by its lagged values and has persistency. Size and CONC have explanatory power to explain LTO and their signs are as expected. Finally, LTA's lagged value is significantly important for LTA variable.

The negative and significant relationships between CONC and dependent variables except for ATO in Table 3 are in line with the findings of Kim et al. (2018) and Çevik (2020). Finally, LTA's lagged value is significantly important for LTA variable. When Size, Leverage, CONC, and Age are controlled in GMM 6 of Table 3, public fixed capital investment variable negatively affects LTA as fixed public investments reduce labor intensity.

\subsection{Robustness Checks}

We employ a number of robustness checks whether our results are stable. Firstly, we check the results using different estimations. For this purpose, we conduct the static panel data analysis. We present static panel estimations in Table 4 for the relationship between public fixed capital investment and profitability with operating efficiency.

In Table 4, $\mathrm{R}^{2}$ fluctuates from 0.98 to 0.23 . F Tests are statistically significant for all estimations. At the same time, we include Hausman Test and Breusch Pagan Test to Table 4. When we look at the static panel estimations to Table 4, we can see that investments are important for profitability and operating efficiency except for ROA and LTA.

For ROA and LTA models of static estimations in Table 4, investments are not statistically significant key variables. Unlike dynamic panel data analysis, LTA model estimation is not statically significant. As a control variable Conc has negative coefficients as expected in general for the models. Similarly, Leverage is a negative explanatory variable for profitability and operating efficiency. On the other hand, Age and Size continues being an important variable for some models. This evidence shows that approximately, the findings in Table 3 and Table 4 are similar to each other. Thus, estimated static panel models in Table 4 approximately confirm previous findings in Table 3.

Secondly for robustness checks, we use the revenue share in the industry and sales as a second measurement for industry share and size data. On the other's hand, we use an alternative winsorize procedure and winsorize 5 percent of the observations. Within this scope, we estimate dynamic panel data analysis with different winsorizing processes and key variables in Table 5. 


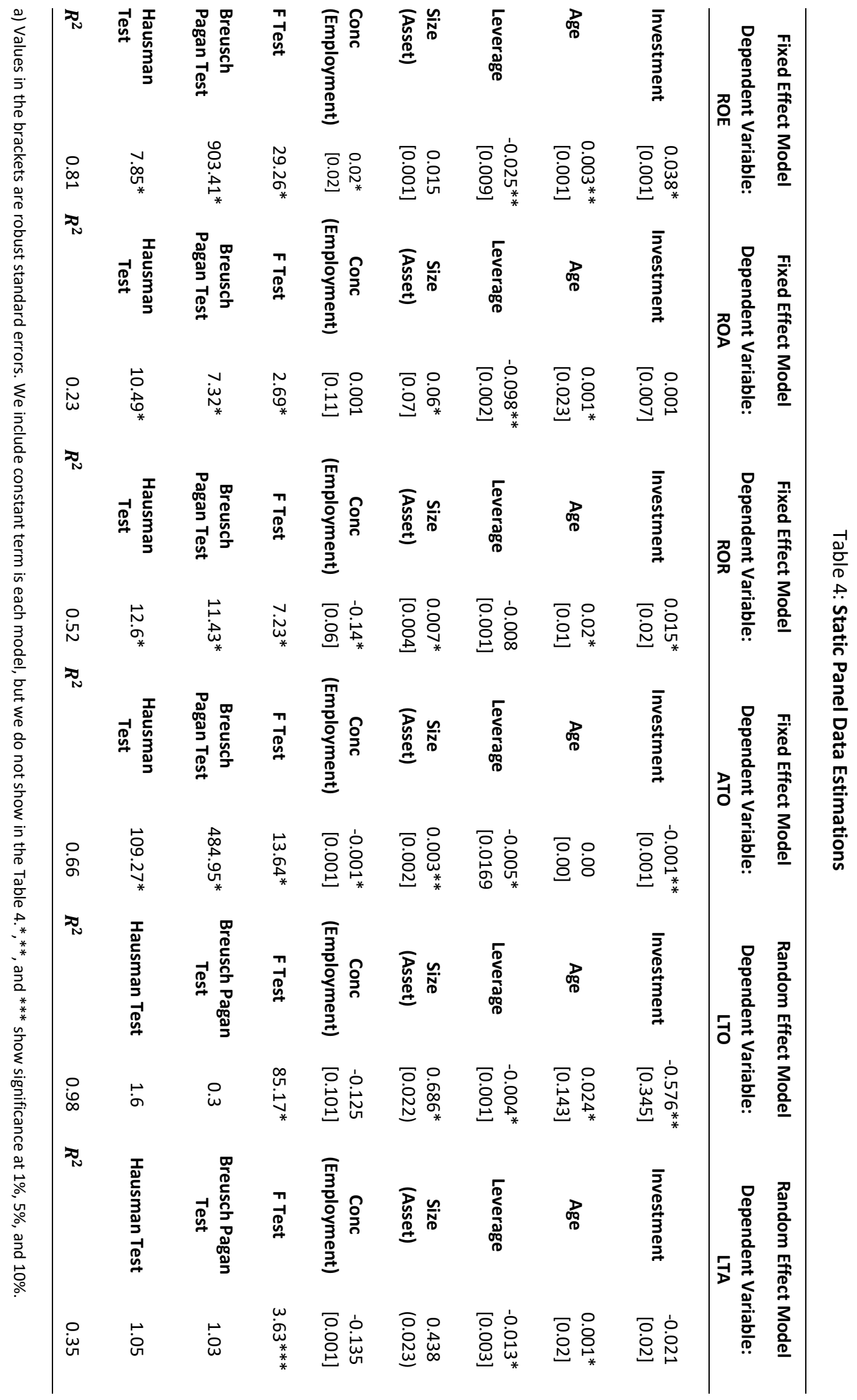




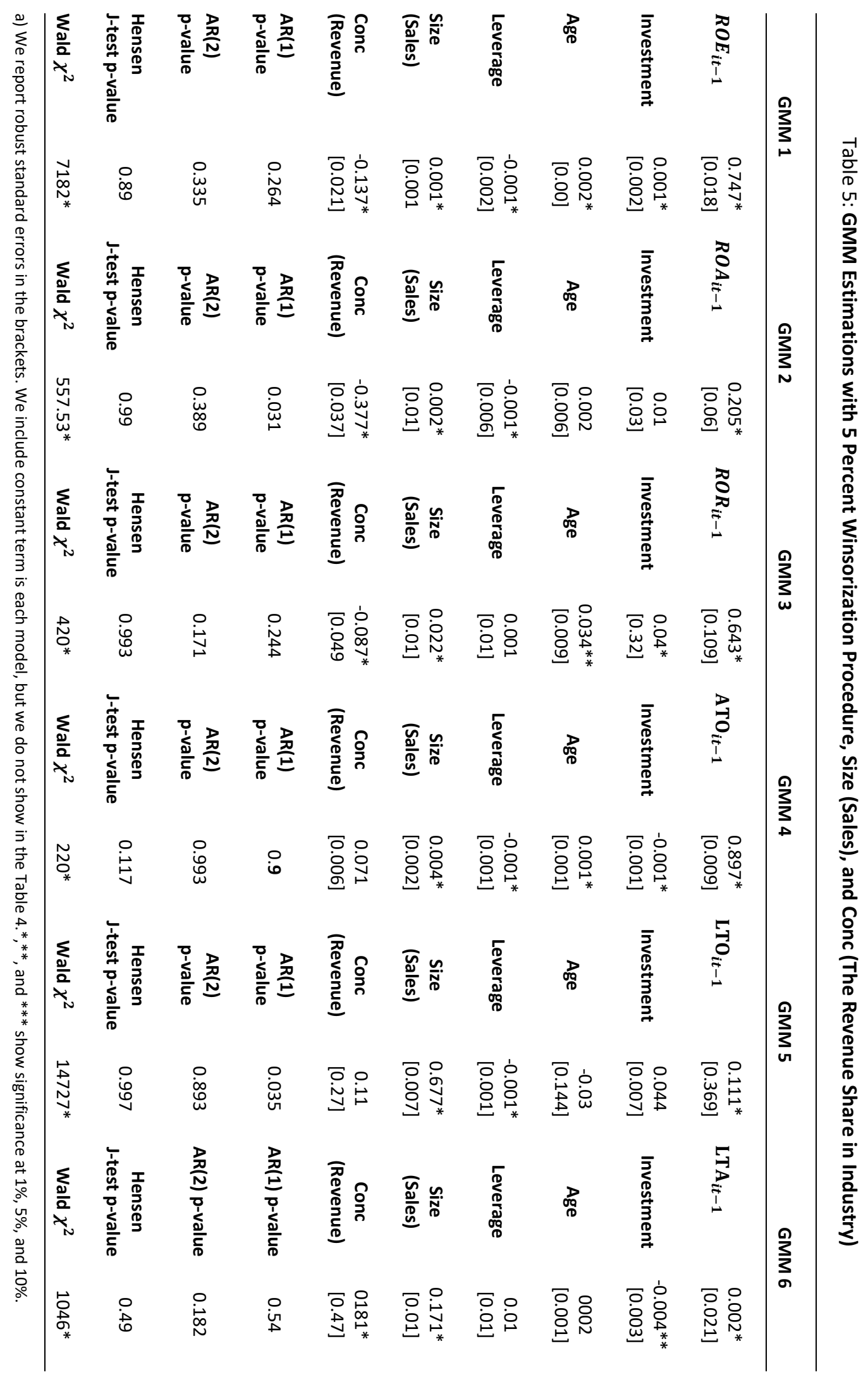


In Table 5, GMM estimations indicate as dependent variables ROE, ROA, ROR, ATO, LTO, and LTA are affected by their lagged values and have persistency. GMM estimations in Table 3 and Table 5 are similar in this context. But, significance levels of control variables differ in Table 5 from Table 3. When we examine the effects of public fixed capital investments, we see that public fixed capital investments are the explanatory variable for all measurements except LTO and ROA. Indeed, these robustness check findings approximate the main findings in Table 3 . In conclusion, we prove that public fixed capital investments are a determining factor for profitability and operating efficiency.

Robustness checks findings of Table 4 and Table 5 show that our results are approximately robust to alternative measurements of key variables and estimations. Both the basic findings and robustness checks carried out with different variables and methods prove that the impact of public fixed capital investments on SOEs' performance is not lost and it is robust.

In addition, we can see on the robustness checks analysis that the revenue share in the sector and sales variables are appropriate variables with the employment share in the sector and total asset. Our main results of Table 3 support the findings of Bahadur (2004), O'toole et al. (2015), and An et al. (2016). As a matter of fact, within the scope of our findings, we see that the positive effect of the increase in fixed capital investments on SOEs' performance is low. However, this trend differs for private sector firms that do not operate in the SOEs' sector.

Although different measurements of profitability and operating efficiency are used in the existing literature, in general for the firms operating in the private sector, Fama and French (1999), Aw et al.(2008), Johansson and Lööf (2008), Lööf and Heshmati (2008), Grazzi et al. (2016), Yu et al. (2017), Amoroso et al. (2017), and Grozdi'c et al. (2020) determine a positive relationship between fixed capital investments and performance. For firms operating in the private sector, the increase in fixed capital investments increases performance, but the increase in fixed capital investments decreases performance for SOEs, as expressed by Pratuckchai and Patanapongse (2012). SOEs are in negative relationship with the increase in fixed capital investments as can be seen from our findings and operate less efficiently than firms operating in the private sector.

$\mathrm{Xu}$ and Yan (2014) argue that for future growth, the governments should increase public fixed capital investment to stimulate the development of the public and private economies. On the other hand, Kim et al. (2019) argue that public investments increase the SOEs performances. But, our findings are not completely compatible with Kim et al. (2019), it is partially compatible with them. Because, fixed capital investments do not positively affect SOEs' performance for all performance indicators in our study and fixed investments are not statistically explanatory significant variable for some performance indicators.

In this study, we find that public fixed capital investments have an impact on profitability and activity efficiency, but we prove that the impact coefficients of public fixed capital investments on dependent variables are low, although they are significant. Similarly, we see this similar finding in Çevik's (2020) study. However, Opie et al. (2019) argue that how firms efficiently use investments is related to ownership and governance structures. When firms are controlled by the government, the government has the incentive to intervene in the operation of SOEs to achieve fiscal, social, and political goals, which can be different from the goal of the value maximization of other shareholders (Shleifer and Vishny, 1994; 1998). Thus, existing literature consistently shows that government control has a negative impact on the investment efficiency of SOEs (Chen et al. 2011; An et al., 2016). Whether fixed capital investments negatively affect financial performance or not, in this way, it brings to mind the issue of the efficiency of the investments. In this respect, when we look at the literature, it can be said that the low impact of public fixed investments on profitability and operating efficiency may be related to the low efficiency of investments. Finally, in brief, we partially accept $\mathrm{H}_{1}$ and $\mathrm{H}_{2}$ in our study. 


\section{Conclusion}

The firm level effects of fixed capital investments, which are generally investigated at the macroeconomic level, is the subject of a limited number of studies. These studies have not a common conclusion regarding the direction of the effect of fixed capital investments on firms' profitability or efficiency and mostly investigate the private investments. This paper is the first attempt to evaluate the effect of public fixed capital investments on the performance of the SOEs in Turkey. The study contributes to the literature by focusing on the relationship between public fixed capital investments and SOEs' performance and investigating the performance from two aspects, profitability and operational efficiency. In addition, it provides policymakers and SOEs' managers with information to support them while taking decisions regarding public fixed capital investment in the future.

In this paper, we analyze the data of 20 non-financial SOEs regarding the period of 2001-2018 using the system GMM technique. As part of the study where we use control variables to capture the firm-level characteristics, we estimate robustness checks with various variables, different winsorize procedures, and methods to test the stability of the findings. The results of dynamic panel data analysis show that public fixed capital investments have no effect on ROA, however, have a low and positive effect on ROE and ROR. It was confirmed that fixed capital investments have a negative effect on ATO, LTO, and LTA, which are considered to represent operational efficiency.

The results of the first robustness checks, which we estimate using static panel data analysis, indicate that public fixed capital investments do not have a significant effect on ROA and LTA. On the other hand, we prove that public fixed capital investments have a low and positive effect on ROE and ROR, however, its effect on ATO and LTO is negative. In the second robustness checks analysis, we use the revenue share in the industry as a second scale and apply an alternative winsorized procedure, which takes $5 \%$ of the observations into account. These analysis results prove that public fixed capital investments are not an explanatory variable for ROA and LTO. In addition, we find that public fixed capital investments have a low and positive effect on ROE and ROR, while it has a negative effect on ATO and LTA.

When we evaluate our study as a whole, our findings show that public fixed capital investments are partially effective in the performance of SOEs. However, this effect, though positive for profitability, is low and partial. On the other hand, the effect of public fixed capital investments on operational efficiency is negative. This indicates that public fixed capital investments cannot sufficiently reflect the SOEs' performance. In this context, Chen et al. (2011) point out that the government ownership in SOEs to support the achievement of social and political objectives such as employment, financial health, regional development, social stability, etc. and this situation changed the investment behavior of SOEs and caused investment inefficiency. Megginson et al. (1994) argue that government ownership can be a coercive force for the overproduction of politically attractive but economically wasteful goods so that capital cannot be properly allocated. In this way, the SOEs move away from the purpose of profit maximization, and their activities are damaged (Baumol, 1984). The present literature consistently implies that state control has a negative effect on the investment efficiency of SOEs (Chen et al., 2011; Ljungqvist et al., 2015 An et al., 2016). Abiad et al. (2015) claim that public fixed capital investments are also more effective in output growth in the countries with higher public investment efficiency. If we go through the literature from this perspective, we can say that the poor effect of public fixed investments on profitability and operational efficiency may be associated with low productivity of investments.

Our findings also have some significant political consequences for SOEs in Turkey. It is possible to argue that the public fixed capital investments, which are expected to provide great advantages for the outputs, are not effective on the performance of SOEs in Turkey at a satisfactory level. Thus, the evaluation of investment productivity is proposed for the agenda.

\section{Uluslararası İktisadi ve İdari İncelemeler Dergisi}


Besides, we can say that reform-based policies, which aim an increase in the sensitivity of investment expenditures to investment opportunities and improve the capital allocation, should be applied. In addition, the results indicate that SOEs managers should be monitored and audited in order to understand to what extent they successfully administer the public fixed capital investments. Such measures may contribute to increase the investment efficiency and thus enhance the performance of SOEs operating in strategic sectors, in Turkey.

\section{References}

Abiad, A., Furceri, D. and Topalova, P. (2015). The Macroeconomic effects of public investment: Evidence from advanced economies. IMF Working Paper, WP/15/95, 1-26.

Aivaziana, V. A., Geb, Y. and Qiu, J. (2005). Can corporatization improve the performance of stateowned enterprises even without privatization?. Journal of Corporate Finance, 11, 791808.

Aktas, N., Croci, E. and Petmezas, D. (2015). Is working capital management value-enhancing? Evidence from firm performance and investments. Journal of Corporate Finance, 30, 98113.

Aljinović B. Z. and Muminović, S.(2013). The impact of capital investments on dairy processing industry features: Evidence from Slovenia, Croatia and Serbia. Mljekarstvo Časopis Za Unaprjeđenje Proizv. I Prerade Mlijeka, 63, 140-149.

Alipour, M., Mohammadi, M. F. S. and Derakhshan, H. (2015). Determinants of capital structure: An empirical study of firms in Iran. International Journal of Law and Management, 57(1), 53-83.

Amoroso, S., Moncada-Paternò-Castello, P. and Vezzani, A. (2017). R\&D profitability: The role of risk and Knightian uncertainty. Small Business Economics, 48, 331-343.

An, H. , Chen, Y. ve Luo, D., Zhang, T. (2016). Political uncertainty and corporate investment: Evidence from China. Journal of Corporate Finance, 36, 174-189.

Arellano, M. and Bover, O. (1995). Another look at the instrumental-variable estimation of errorcomponents models. Journal of Economics, 68(1), 29-52.

Arnull-Almond, B. (2008). The prediction of Australian targets: A binomial and multinomial logit analysis (Unpublished Doctoral Dissertation). The University of Sydney.

Assagaf, A. and Ali, H. (2017). Determinants of financial performance of state-owned enterprises with government subsidy as moderator. International Journal of Economics and Financial Issues, 7(4), 330-342.

Aw, B.Y., Mark, J. R. and Daniel, Y. X. (2008). R\&D investments, exporting, and the evolution of firm productivity. American Economic Review, 98, 451-456.

Bahadur, F. K. C. (2004). Performance of public enterprises in Nepal. NRB Economic Review (Occasional Paper), 15, 203-226.

Bałtowski, M., and Kozarzewski, P. (2016). Formal and real ownership structure of the Polish economy: State-owned versus state-controlled enterprises. Post-Communist Economies, 28(3), 1-15.

Baumol, W. J. (1984). Toward a theory of public enterprise. Atlantic Economic Journal, 12,13-20.

Bavon, A. (1998). Does ownership matter? Comparing the performance of public and private enterprises in Ghana. The Journal of Developing Areas. 33(1), 53-72.

Bernier, L. (2014). Public enterprises as policy instruments: The importance of public entrepreneurship. Journal of Economic Policy Reform, 17(3), 253-256. 
Billon, S. and Gillanders, R. (2014). State ownership and corruption. HECER Discussion Paper, 378, 1-20.

Blundell, R. and Bond, S. (1998). Initial conditions and moment restrictions in dynamic panel data models. Journal of Economics, 87(1), 115-143.

Boardman, A. E. and Vining, A. R. (1989). Ownership and performance in competitive environments: A comparison of the performance of private, mixed, and state-owned enterprises. Journal of Law and Economics, 32, 1-33.

Boycko, M., Shliefer, A. and Vishny, R. (1993). Privatizing Russia. Brookings Papers on Economic Activity, 2, 139-192.

Bradbury, M. E. (1999). Government ownership and financial performance in a competitive environment: Evidence from the corporatisation of the New Zealand Government computing services. Asia Pacific Journal of Management, 16, 157-172.

Bradbury, M. E. and Hooks, J. J. (2008). Ownership and performance in a lightly regulated noncompetitive operating environment. Paper presented at Accounting and Finance Association of Australia and New Zealand (AFAANZ)/International Association for Accounting Education and Research (IAAER) 2008 conference, Sydney, Australia.

Chan, K. K. Y., Chen L. and Wong, N. (2018). New Zealand state-owned enterprises: Is stateownership detrimental to firm performance?. New Zealand Economic Papers, 52(2), 170-184.

Chen, S., Sun, Z., Tang, S. and Wu, D. (2011). Government intervention and investment efficiency: Evidence from China. Journal of Corporate Finance, 17, 259-271

Christiansen, H. (2011). The size and composition of the SOE sector in OECD countries. Paris: OECD Publishing.

Çevik, S. (2020). You are suffocating me: Firm-level analysis of state-owned enterprises and private investment. Journal of Comparative Economics, 48, 292-301.

De Long, J. B. and Summers, L. H. (1991). Equipment investment and economic growth. Quarterly Journal of Economics, 106 (2), 445-502.

Dewenter, K. L. and Malatesta, P. H. (2001). State-owned and privately-owned firms: An empirical analysis of profitability, leverage, and labour intensity. American Economic Review, 91, 320-334.

Dollar, D. and Wei, S. J. (2007). Das (Wasted) kapital: Firm ownership and investment efficiency in China. National Bureau of Economic Research Working Paper. 13103, 1-40.

Ejelly, A. M. A. (2009). Ownership and firm performance: The experience of Saudi Arabia's emerging economy. International Business and Economics Research Journal, 8, 25-34.

Fama, E. F. and French, K. R. (1999). The corporate cost of capital and the return on corporate investment. Journal of Finance, 54, 1939-1967.

Fernández-Rodríguez, E., García-Fernández, R. and Martínez-Arias, A. (2019). Influence of ownership structure on the determinants of effective tax rates of Spanish companies. Sustainability, 11(5), 1441.

Gal, P. (2013). Measuring total factor productivity at the firm level using OECD-ORBIS. OECD Economics Department Working Papers No. 1049. OECD, Paris.

Goldeng, E., Grünfeld, L. A. and Benito, G. R. G. (2008). The performance differential between private and state owned enterprises: The roles of ownership, management and market structure. Journal of Management Studies, 45(7), 1244-1273.

\section{Uluslararası İkisadi ve İdari İncelemeler Dergisi}


Grazzi, M., Nadia, J. and Tania, T. (2016). Dynamics of investment and firm performance: Comparative evidence from manufacturing industries. Empirical Economics, 51, 125179.

Grozdi'c, V., Mari'c, B., Radiši'c, M., Šebestová, J. and Lis, M. (2020). Capital investments and manufacturing firms' performance: Panel-Data analysis. Sustainability, 12, 1-18.

Hemming, R. and Mansoor, A.M. (1987). Privatization and public enterprises. IMF Working Paper, WP/87/9, 1-59.

Huang, Y. (2019). Government intervention and corporate investment efficiency: Evidence from China. Journal of Service Science and Management, 12, 267-276.

İncekara, A. (1989). Kiт'ler ve özelleştirme. İstanbul Üniversitesi İktisat Fakültesi Mecmuası. 47(14), 151-166.

Jindrichovska, I., Ugurlu, E. and Kubickova, D. (2013). Changes in capital structure of Czech SMEs: A dynamic panel data approach. Ekonomika a Management, 3, 1-19.

Joh, S. W. (2003). Corporate governance and firm profitability: Evidence from Korea before the economic crisis. Journal of Financial Economics, 68(2), 287-322.

Johansson, B. and Lööf, H. (2008). The impact of firm's R\&D strategy on profit and productivity. CESIS Electronic Working Paper Series. Paper No. 156.

Kabaciński, B., Kubiak, J. and Szarzec, K. (2020). Do state-owned enterprises underperform compared to privately owned companies? An examination of the largest Polish Enterprises. Emerging Markets Finance and Trade, 1-19.

Kalemli-Özcan, Ş., Sorensen, B., Villegas-Sanchez, C., Volosovych, V. and Yeşiltaş, S. (2015). How to construct nationally representative firm-level data from the ORBIS Global Database. National Bureau of Economic Research, Cambridge, MA NBER Working Papers No. 21558.

Keefer, P. and Knack, S. (2007). Boondoggles, rent-seeking, and political checks and balances: Public investment under unaccountable governments. Review of Economics and Statistics, 89, 566-572.

Khan, M. S. and Reinhart, C. M. (1990). Private investment and economic growth in developing countries. World Development, 18(1), 19-27.

Kim, S., Shin, H-H. and Yu, S. (2019). Performance of state-owned enterprises during public elections: The case of Korea. Emerging Markets Finance and Trade, 55(1), 78-89,

Köseoğlu, M. (2005). Kamu iktisadi teşebbüslerinde performans ölçümü. Yıllık Programlar ve Konjonktür Değerlendirme Genel Müdürlüğü KiT ve Sosyal Güvenlik Dairesi Daire Başkanlığı (Uzmanlık Tezi). DPT: 2688.

Lev, B. and Thiagarajan, S. R. (1993). Fundamental information analysis. Journal of Accounting Research. 31(2), 190-215.

Levine, R. and Renelt, D. (1992). A sensitivity analysis of cross-country growth regressions. American Economic Review, 82, 942-63.

Lipsey, R. and Kravis, I. (1987). Saving and economic growth: Is the United States really falling behind?, New York: The Conference Board.

Ljungqvist, A., Chen, D., Jiang, D., Lu, H. and Zhou, M. (2015). State Capitalism vs. Private Enterprise. NBER Working Paper, 20930, 1-54. 
Lööf, H. and Heshmati, A. (2008). Investment and performance of firms: Correlation or causality?. Corporate Ownership Control, 6, 268-282.

Mankiw, N. G., Romer, D. and Well, D. N. (1992). A contribution to the empirics of economic growth. Quarterly Journal of Economics, 107, 407-437.

Maria-Dolores, R. (2004). Public capital effects on Spanish regions productivity: a non-parametric approach (1965-1998). Hacienda Pública Española / Revista de Economía Pública, 171 (4), 57-74.

Megginson, W. L. and Netter, J. M. (2001). From state to market: a survey of empircal studies of privatization. Journal of Economic Literature, 39, 321-389. However, this effect, though positive for profitability, is low and partial.

Megginson, W. L., Nash, R. C. and Randenborgh, M. V. (1994). The financial and operating performance of newly privatized firms: An international empirical analysis. The Journal of Finance. XLIX(2), 403-453.

Naveed, S., Salman, Y., Jabeen, N., Jadoon, M. Z. I. and Irfan, S. (2018). Governance and management of state- owned enterprises in Pakistan. Pakistan Economic and Social Review, 56(1), 47-66.

O'Toole, M. C., Morgenroth, E. and Thuy, H. T. T. (2015). Investment Efficiency, State-Owned Enterprises and Privatisation: Evidence from Vietnam in Transition. ESRI Working Paper. 498, 1-30.

OECD (2016). Broadening the ownership of state-owned enterprises: A comparison of governance practices. OECD Publishing, Paris. http://dx.doi.org/10.1787/978926424 4603-en

OECD (2018), Ownership and governance of state-owned enterprises: A compendium of national practices. http://www.oecd.org/corporate/ca/Ownership-and-Governance-of-State-Ow ned-Enterprises-A-Compendium-of-National-Practices.pdf.

Opie, W., Tian, G. G. and Zhang, H. F. (2029). Corporate pyramids, geographical distance, and investment efficiency of Chinese state-owned enterprises. Journal of Banking and Finance, 99, 95-120.

Pratuckchai, W. and Patanapongse, W. (2012). The study of management control systems in state owned enterprises: A proposed conceptual framework. The International Journal of Organizational Innovation, 5(2), 83-115.

Qi, H. and Kotz, D. M. (2019). The impact of state-owned enterprises on China's economic growth. Review of Radical Political Economics, January, 1-19.

Robinson, J. A. and Torvik, R. (2005). White Elephants. Journal of Public Economics, 89(2-3), $197-$ 210.

Shleifer, A. and Vishny, R. W. (1994). Politicians and firms. The Quarterly Journal of Economics, 109(4), 995-1025.

Shleifer, A. and Vishny, R. W. (1998). The grabbing hand: Government pathologies and their cures. Cambridge, MA: Harvard University Press.

Singh, J. N. and Chen, G. C. (2017). State-owned enterprises and the political economy of statestate relations in the developing world. Third World Quarterly, 1-21.

Stein, J.C. (2003). Agency, information and corporate investment. Handbook of the Economics of Finance, 1, 111-165.

\section{Uluslararası İkisadi ve İdari İncelemeler Dergisi}


Sudiyatno, B., Puspitasari, E. and Kartika, A. (2012). The company's policy, firm performance, and firm Value: An empirical research on Indonesia Stock Exchange. American International Journal of Contemporary Research, 2(12), 30-40.

Szarzec, K. and Nowara, W. (2017). The economic performance of state-owned enterprises in Central and Eastern Europe. Post-Communist Economies, 29(3), 375-91.

Ministery of the Republic of Turkey, Supreme Audit Institution Report (2012). Supreme Audit Institution from General Supervision Committee to the TCA (1938-2010). https:// www.sayistay.gov.tr/tr/Upload/95906369/files/yayinlar/yuksek_denetleme_kurulu_tari hcesi.pdf

Turkish Court of Accounts (2017). Public Enterprises 2016 General Report. https://www. sayistay.gov.tr/tr/Upload/62643830/files/raporlar/genel_raporlar/kit_genel/2016_ki.pdf

Turkish Court of Accounts (2019). Public Enterprises 2018 General Report.https://www. sayistay.gov.tr/tr/Upload/62643830/files/raporlar/genel_raporlar/kit_genel/2018_Ki.pd $f$.

The Tenth Development Plan (2014). Türkiye Cumhuriyeti Kalkınma Bakanlığı. http://www .sbb.gov.tr/wp-content/uploads/2018/11/Onuncu-Kalk\%C4\%B1nma-Plan\%C 4\%B1-2014-2018.pdf (Acces Date: 01.07.2020).

Tvaronavičius, V. and Tvaronavičiene, M. (2008). Role of fixed investments in economic growth of country: Lithuania in European context. Journal of Business Economics and Management. 9(1), 57-64.

$\mathrm{Xu}, \mathrm{X}$. and Yan, Y. (2014) Does government investment crowdout private investment in China?, Journal of Economic Policy Reform, 17(1), 1-12.

Yu, X., Dosi, G., Grazzi, M. and Lei, J. (2017). Inside the virtuous circle between productivity, profitability, investment and corporate growth: An anatomy of Chinese industrialization. Research Policy, 46, 1020-1038. 